\title{
Cuban Brown Anoles (Anolis sagrei) in the Turks \& Caicos Islands
}

\author{
Joseph Burgess \\ Guana Tolomato Matanzas National Estuarine Research Reserve \\ Ponte Vedra, Florida 32082, USA \\ Photographs by the author.
}

$\mathrm{T}$ The Cuban Brown Anole (Anolis sagrei) is a trunkground species indigenous to Cuba and its satellites, the Bahama Islands, and Little Cayman Island. The species has been widely introduced throughout the West Indies (Jamaica [which may or may not have been human-mediated], Grand Cayman, Swan Island, Grenada, St. Vincent, the Grenadines [Canouan], Barbados, St.-Martin [although possibly extirpated there; M. Yokoyama 2012], St. Lucia) and beyond (including the Atlantic Coast of México to Belize, Islas de la Bahía, Aruba, Hawaii [Oahu and Coconut Island, Kauai], Taiwan, the southeastern United States, and California [Orange County]) (Henderson and Powell 2009, Fläschendräger 2010, Morton and Cox 2011). Previously recorded maximum SVL in the West Indies was $70 \mathrm{~mm}$ in males (Schwartz and Henderson 1991) and $47.8 \mathrm{~mm}$ in females (Rodríguez Schettino, 1999). These lizards prefer open, sunny habitats and often are abundant in edificarian and other disturbed sites (Schwartz and Henderson 1991, Henderson and Powell 2009).

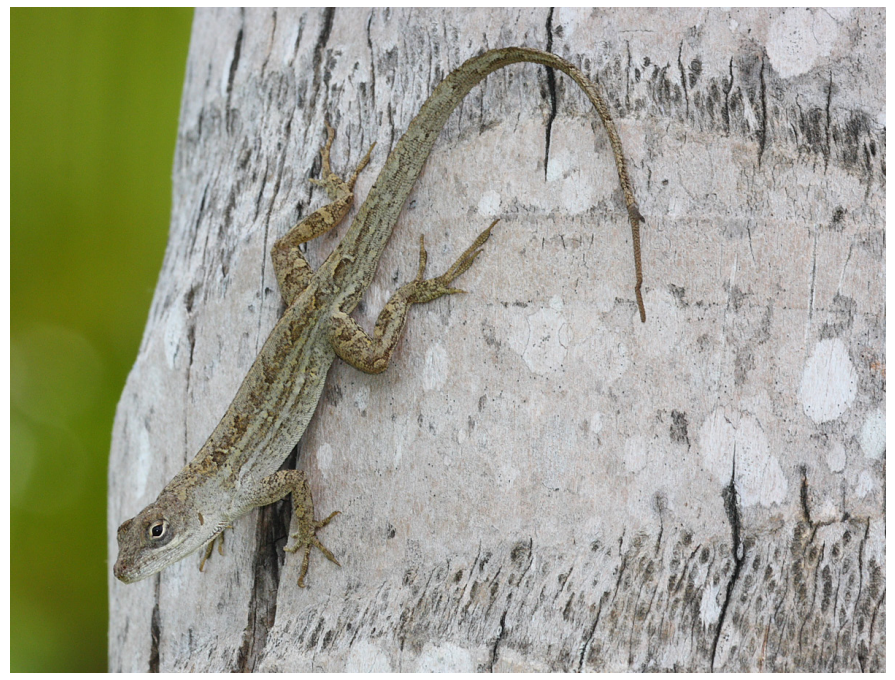

On 28 September 2012 at 1325 h, I observed two adult males in Grace Bay, Providenciales Island, Turks \& Caicos Islands ( $\left.21^{\circ} 47^{\prime} 48^{\prime \prime} \mathrm{N}, 72^{\circ} 10^{\prime} 18^{\prime \prime} \mathrm{W}\right)$. The anoles were perched approximately $1.5 \mathrm{~m}$ above the ground on the trunks of nonnative Coconut Palms (Cocos nucifera). This location was on a roadside adjacent to a landscape nursery.

At $1015-1125$ h on 5 October 2012, I performed a rapid assessment of about one hectare surrounding the site where the species had first been located. During that time I visually documented 17 Anolis sagrei (with five others for which I was unable to ascertain species) and only three native $A$. scriptus. I captured two adult males and one adult female of the former species. They measured $69 \mathrm{~mm}, 73 \mathrm{~mm}$, and $48 \mathrm{~mm}$, respectively, so one of the males and the female exceeded previously documented records for West Indian populations of the species. Robert Powell confirmed the identity of the specimens from photographs taken at the site. Color photographic vouchers were deposited in the Milwaukee Public Museum (MPM P767). This increases the total number of

Male (left) and female Cuban Brown Anoles (Anolis sagrei) from Providenciales, Turks \& Caicos Islands.

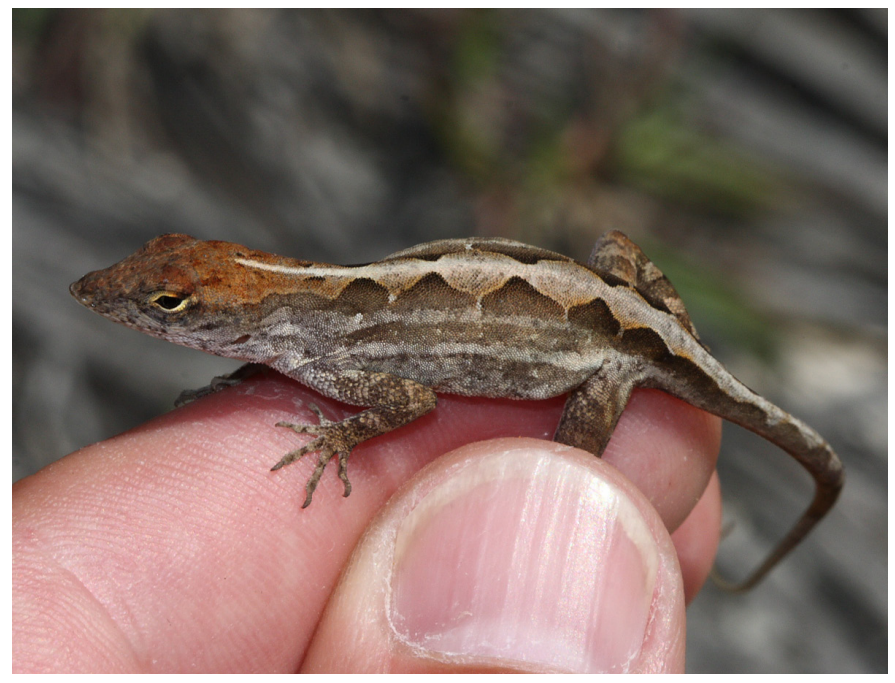


established non-native lizard species on Providenciales to three (Reynolds 2011).

\section{Literature Cited}

Fläschendräger, A. 2010. Cuban Brown Anoles (Anolis sagrei) in St. Maarten. Reptiles \& Amphibians 17:121-122.

Henderson, R.W. and R. Powell. 2009. Natural History of West Indian Reptiles and Amphibians. University Press of Florida, Gainesville.

Morton, M.N. and C.A. Cox. 2011. Cuban Brown Anoles (Anolis sagrę) in Saint Lucia. Reptiles \& Amphibians 18:52-53.

Reynolds, R.G. 2011. Status, conservation, and introduction of amphibians and reptiles in the Turks and Caicos Islands, British West Indies, pp. 377-406. In: A. Hailey, B.S. Wilson, and J.A. Horrocks (eds.), Conservation of Caribbean Island Herpetofaunas. Volume II: Regional Accounts of the West Indies. Brill, The Netherlands.

Rodríguez Schettino, L. 1999. Systematic accounts of the species, pp. 104-380. In: L. Rodríguez Schettino (ed.), The Iguanid Lizards of Cuba. University Press of Florida, Gainesville.

Schwartz, A. and R.W. Henderson 1991. Amphibians and Reptiles of the West Indies: Descriptions, Distributions, and Natural History. University of Florida Press, Gainesville.

Yokoyama, M. 2012. Reptiles and amphibians introduced on St. Martin. Reptiles \& Amphibians 19: in press. 